\title{
Continuous low-dose infusion of tumor necrosis factor alpha in adipose tissue elevates adipose tissue interleukin 10 abundance and fails to alter metabolism in lactating dairy cows
}

\author{
Cynthia A. Martel, ${ }^{*}$ Laman K. Mamedova, ${ }^{*}$ J. Ernest Minton, ${ }^{*}$ Meredyth L. Jones, $\dagger^{1}$ Jeff A. Carroll, $\ddagger$ \\ and Barry J. Bradford*2 \\ *Department of Animal Sciences and Industry, and \\ †Veterinary Medical Teaching Hospital, Kansas State University, Manhattan 66506 \\ łLivestock Issues Research Unit, Agricultural Research Service, USDA, Lubbock, TX 79403
}

\begin{abstract}
Repeated bolus doses of tumor necrosis factor- $\alpha$ (TNFo) alters systemic metabolism in lactating cows, but whether chronic release of inflammatory cytokines from adipose tissue has similar effects is unclear. Latelactation Holstein cows ( $\mathrm{n}=9-10 /$ treatment) were used to evaluate the effects of continuous adipose tissue $\mathrm{TNF} \alpha$ administration on glucose and fatty acid (FA) metabolism. Cows were blocked by feed intake and milk yield and randomly assigned within block to control or TNFo treatments. Treatments $(4 \mathrm{~mL}$ of saline or 14 $\mu \mathrm{g} / \mathrm{kg}$ of $\mathrm{TNF} \alpha$ in $4 \mathrm{~mL}$ of saline) were infused continuously over $7 \mathrm{~d}$ via 2 osmotic pumps implanted in a subcutaneous adipose depot. Plasma, milk samples, milk yield, and feed intake data were collected daily, and plasma glucose turnover rate was measured on $\mathrm{d} 7$. At the end of $d 7$, pumps were removed and liver and contralateral tail-head adipose biopsies were collected. Results were modeled with the fixed effect of treatment and the random effect of block. Treatment with $\mathrm{TNF} \alpha$ increased plasma concentrations of the acute phase protein haptoglobin, but did not alter plasma TNF $\alpha$, IL-4, IL-6, or IFN- $\gamma$ concentrations, feed intake, or rectal temperature. Milk yield and composition were unchanged, and treatments did not alter the proportion of short- versus long-chain FA in milk on d 7 . Treatments did not alter plasma free FA concentration, liver triglyceride content, or plasma glucose turnover rate. Surprisingly, TNFo infusion tended to decrease liver TNFo and IL-1 receptor $1 \mathrm{mRNA}$ abundance and significantly increased adipose tissue IL-10 protein concentration. Continuous infusion of TNFa did not induce the metabolic responses previously observed following bolus doses delivered at the same rate per
\end{abstract}

Received November 27, 2013.

Accepted April 17, 2014.

${ }^{1}$ Current address: Department of Large Animal Clinical Sciences, Texas A\&M University, College Station 77843.

${ }^{2}$ Corresponding author: bbradfor@ksu.edu day. Metabolic homeostasis may have been protected by an adaptive anti-inflammatory response to control systemic inflammation.

Key words: cytokine, inflammation, adipose tissue, liver

\section{INTRODUCTION}

Tumor necrosis factor- $\alpha$ ( $\mathbf{T N F} \boldsymbol{\alpha})$ is a proinflammatory cytokine that was first described as cachectin, which was implicated in wasting disease following sepsis (Cerami et al., 1985). As an inflammatory mediator, $\mathrm{TNF} \alpha$ plays an important role in activating components of the innate immune system in response to pathogen challenges or sterile inflammatory signals (Fiers, 1991); however, nearly all cell types express receptors for $\mathrm{TNF} \alpha$, and its reported systemic effects are pleiotropic (Olefsky and Glass, 2010). It is becoming increasingly apparent that $\mathrm{TNF} \alpha$ and other cytokines play a central role in metabolic physiology, not only in acute situations, such as sepsis, but also in chronic inflammatory scenarios (Popa et al., 2007).

It is now widely accepted that TNFQ is produced in adipose tissue, derived from resident macrophages and possibly adipocytes (Hotamisligil et al., 1993; Olefsky and Glass, 2010). Circulating TNFo concentrations are chronically elevated in obese individuals in several species, including sheep (Daniel et al., 2003), and the resulting inflammatory state is thought to contribute to insulin insensitivity and hepatic lipid accumulation in these individuals (Shoelson et al., 2007).

Dairy cattle commonly show signs of inflammation early in lactation (Bionaz et al., 2007). This phenomenon is likely directly related to the parturition process, but the inflammatory state is amplified in cows with excess adipose stores at the time of parturition (Ametaj et al., 2005). Excess adiposity is also a key risk factor for the development of fatty liver, one of the most prevalent metabolic disorders in dairy cattle (Bobe et al., 2004). Tumor necrosis factor- $\alpha$ promotes mobiliza- 
tion of energy stores by decreasing insulin sensitivity (Kushibiki et al., 2001) and feed intake (Kushibiki et al., 2003) and by directly stimulating lipolysis (Kushibiki et al., 2002), which are all changes associated with bovine fatty liver disease. Furthermore, TNFo can directly stimulate hepatic triglyceride (TG) synthesis and accumulation (Endo et al., 2007).

Previous work in lactating dairy cattle supported a direct effect of $\mathrm{TNF} \alpha$ on $\mathrm{TG}$ accumulation and metabolic gene expression in the liver (Bradford et al., 2009). Subcutaneous administration of TNFo $(2 \mu \mathrm{g} /$ $\mathrm{kg}$ of BW) to late-lactating dairy cows once daily for $7 \mathrm{~d}$ significantly increased liver TG concentration and altered transcript profiles in a manner consistent with a shift from FA oxidation to TG storage (Bradford et al., 2009). In early lactation cows, a similar treatment regimen did not have clear effects on intermediary metabolism, but substantially decreased feed intake and milk production (Yuan et al., 2013). Thus, the objective of the present experiment was to determine whether continuous administration of the same total dose of $\mathrm{TNF} \alpha$ into adipose tissue would cause similar alterations in systemic nutrient metabolism or productivity.

\section{MATERIALS AND METHODS}

\section{Animals, Treatments, and Data and Sample Collection}

Experimental procedures were approved by the Institutional Animal Care and Use Committee at Kansas State University (protocol \#2753). Nineteen late-lactation Holstein cows were used, rather than early lactation cows, to ensure that animals began the experiment without hepatic inflammation and to decrease animal variability. Cows $(687 \mathrm{~kg}$ of $\mathrm{BW}, \mathrm{SD}=$ $66 \mathrm{~kg}$ ) entered a tiestall facility $7 \mathrm{~d}$ before treatment to allow for environmental adaption. Cows were offered water ad libitum, fed twice daily, and milked 3 times daily in a milking parlor. The diet fed throughout the study (Table 1) was formulated to meet all nutrient requirements (NRC, 2001). Following the adaption period, cows were blocked by pretreatment feed intake and milk production and assigned randomly within block to control $(\mathrm{n}=10)$ or TNFa $(\mathrm{n}=9)$ treatments. Recombinant bovine TNF $\alpha$ was produced (GenScript, Piscataway, NJ) as previously described (Bradford et al., 2009). Saline $(4 \mathrm{~mL})$ or TNFo $(14 \mu \mathrm{g} / \mathrm{kg}$ in $4 \mathrm{~mL}$ of saline) was infused continuously over $7 \mathrm{~d}$ via 2 osmotic pumps (2ML1, Alzet, Cupertino, CA) implanted in the adipose layer in the tail-head region. The region between the tail-head and the pin bone was surgically prepared, and $2 \mathrm{~mL}$ of $2 \%$ lidocaine hydrochloride was injected subcutaneously to produce local anesthesia.
Table 1. Ingredient and nutrient composition of the diet

\begin{tabular}{lc}
\hline Item, \% of DM & Measurement \\
\hline Diet ingredient & \\
Corn gluten feed & 30.8 \\
Corn silage & 20.8 \\
Ground corn & 18.0 \\
Alfalfa hay & 16.5 \\
Cottonseed & 5.3 \\
Expeller soybean meal & 4.7 \\
Calcium salts of FA & 0.7 \\
Cane molasses & 0.5 \\
Menhaden fish meal & 0.3 \\
Mineral and vitamin mix 1 & 2.4 \\
Nutrient composition & \\
OM & 92.1 \\
NDF & 33.4 \\
Starch & 23.5 \\
CP & 17.2 \\
Ether extract & 4.3
\end{tabular}

${ }^{1}$ Contained (per kilogram of DM): Ca, 188 g; Na, 97 g; Cl, 15 g; Mg, 28 g; Fe, 2.0 g; K, 600 mg; Zn, 586 mg; Mn, 330 mg; S, 200 mg; P, 100 mg; $\mathrm{Cu}, 181 \mathrm{mg}$; Co, $36 \mathrm{mg}$; Se, $7.7 \mathrm{mg}$; I, $1.8 \mathrm{mg}$; all-trans retinyl acetate, $33 \mathrm{mg}$; cholecalciferol, $1.0 \mathrm{mg}$; all-rac- $\alpha$-tocopherol, $2.0 \mathrm{~g}$.

An incision $(\sim 2 \mathrm{~cm})$ was made with a sterile scalpel, and the skin was separated from the underlying tissue by blunt dissection $(3 \times 3 \mathrm{~cm}$ region $)$ for pump implantation. The incision was closed with surgical staples.

Throughout the 7-d treatment period, blood plasma, milk samples, milk yield data, and DMI data were collected daily. Two blood samples were collected $(0800 \mathrm{~h})$ from the coccygeal vein into evacuated tubes containing potassium EDTA or potassium oxalate with sodium fluoride as a glycolytic inhibitor (Vacutainer, Becton Dickinson, Franklin Lakes, NJ) and centrifuged (2,000 $\times \mathrm{g}$ for $10 \mathrm{~min}$ at $25^{\circ} \mathrm{C}$ immediately after collection); plasma was stored at $-20^{\circ} \mathrm{C}$. On d 5 of treatment, jugular catheters were placed and at least $18 \mathrm{~h}$ of recovery was allowed before sample collection via the catheters. On treatment d 7, an initial blood sample was collected (into sodium fluoride tubes), cows were given a glucose bolus containing $\mathrm{U}_{-}{ }^{13} \mathrm{C}$-glucose (99\% atom, Sigma Chemical Co., St. Louis, MO) via the jugular catheter, and blood samples were then collected at 10-min intervals for $120 \mathrm{~min}$ to determine glucose turnover rate (Schulze et al., 1991). Each cow received approximately $1 \mathrm{~g}$ of $\mathrm{U}_{-}{ }^{13} \mathrm{C}$-glucose in $50 \mathrm{~mL}$ of sterile saline; syringes were weighed immediately before and after infusion to determine the exact amount administered. Catheters were flushed with a sterile solution of $3.5 \%$ sodium citrate after the labeled glucose bolus $(20 \mathrm{~mL})$ and after each blood sample collection $(5 \mathrm{~mL})$. Cows were fed every $2 \mathrm{~h}$, beginning $6 \mathrm{~h}$ before administration of the labeled glucose and continuing through the final sample collection to promote steady-state glucose kinetics.

After the glucose turnover assay was completed, osmotic pumps were removed and checked for any resid- 
ual solution; all pumps were found to be empty. Liver and contralateral tail-head adipose tissue samples were then collected for analysis of liver TG and abundance of key transcripts. Liver biopsies were collected as previously described (Mullins et al., 2012). For adipose tissue biopsies, the region between the tail-head and the pin bone (contralateral to the site of pump insertion) was surgically prepared and $2 \mathrm{~mL}$ of $2 \%$ lidocaine hydrochloride was injected subcutaneously to produce local anesthesia. An incision $(\sim 3 \mathrm{~cm})$ was made with a sterile scalpel, and subcutaneous adipose tissue samples were collected using sterile forceps and surgical scissors. After approximately $5 \mathrm{~g}$ of tissue was collected, the incision was closed with surgical staples.

\section{Milk Analyses}

During the treatment period, a single milk sample was collected from each cow at each milking and divided. One sample was analyzed by Heart of America DHIA (Manhattan, KS) to determine concentrations of fat, true protein, and lactose, as previously described (Mullins et al., 2012). The second sample was used for FA analysis as described by Sukhija and Palmquist (1988). Prior to FA analysis, samples were thawed, shaken, and $200 \mu \mathrm{L}$ were aliquoted for lyophilization. Lyophilized samples were resuspended in $1 \mathrm{~mL}$ of hexane containing $\mathrm{C} 13: 0$ as an internal standard and methylated using $\mathrm{BF}_{3}$-methanol. The resulting $\mathrm{FA}$ methyl esters were extracted in hexane and injected onto a Supelco (Bellefonte, PA) SP-2560 capillary gas chromatography column $(100 \mathrm{~m} \times 0.25 \mathrm{~mm} \times 0.2 \mu \mathrm{m})$ for FA profile analysis, with a run time of $67 \mathrm{~min}$.

\section{Plasma Analyses}

Colorimetric kits were used to quantify glucose, NEFA, BHBA, and insulin concentrations in all plasma samples as previously described (Bradford et al., 2009). Bovine-specific ELISA assays were used to quantify insulin (Mullins et al., 2012) and TNFo (Farney et al., 2011) concentrations in samples collected on d 7. Additionally, a multiplexed bovine cytokine ELISA assay (Searchlight, Bovine Cytokine Array; Aushon Biosystems; Billerica, MA) was used to determine IFN $\gamma$, IL-6, and IL-4 concentrations in plasma samples collected on d 7; this assay system has been previously described (Carroll et al., 2009). Haptoglobin was analyzed by a colorimetric method based on peroxidase activity (Cooke and Arthington, 2013). The standard curve was prepared using plasma samples (Yuan et al., 2013) determined by ELISA (kit \#2410-7; Life Diagnostics, West Chester, PA).
Plasma samples collected for the glucose turnover assay were analyzed for $\mathrm{U}_{-}{ }^{13} \mathrm{C}$-glucose enrichment (Metabolic Solutions, Inc., Nashua, NH). Glucose was extracted and converted to aldonitrile pentaacetate derivative (Tserng and Kalhan, 1983), and negative chemical ionization GC-MS (Hewlett-Packard 5890) was used to analyze derivatized samples. The isotopic composition of the glucose was determined by monitoring unlabeled $(\mathrm{M}+0: \mathrm{m} / \mathrm{z}=328)$ versus $\mathrm{U}_{-}{ }^{13} \mathrm{C}$-labeled $(\mathrm{M}+6: \mathrm{m} / \mathrm{z}=334)$ glucose derivatives. This approach, as opposed to oxidation of glucose and measurement of $\mathrm{CO}_{2}$ enrichment, ensures that results are not biased by carbon recycling via the Cori cycle. Enrichment of plasma glucose for each animal was fitted to an exponential decay curve according to the equation

$$
\mathrm{E}_{t}=\mathrm{E}_{0} \times e^{-k t}
$$

where $t=$ time relative to infusion $(\min ) ; \mathrm{E}_{t}=$ enrichment of plasma glucose $\left(\mathrm{U}_{-}{ }^{13} \mathrm{C}\right.$-glucose: unlabeled glucose ratio) at time $t ; \mathrm{E}_{0}=$ enrichment at time $t=0$; and $k=$ rate constant $\left(\min ^{-1}\right)$. After using the best-fit equations to determine $k$ and $\mathrm{E}_{0}$, the total glucose pool was calculated by the equation

$$
\mathrm{G}=\mathrm{M} \div \mathrm{E}_{0},
$$

where $\mathrm{G}=$ total glucose pool $(\mathrm{g})$ and $\mathrm{M}=$ mass of tracer infused $(\mathrm{g})$. Plasma glucose turnover rate (GTR, $\mathrm{g} / \mathrm{min})$ was calculated as $\mathrm{GTR}=\mathrm{G} \times k$. Samples collected 10 min before infusion of $\mathrm{U}_{-}{ }^{13} \mathrm{C}$-glucose were also analyzed to verify the lack of natural occurrence of the $\mathrm{M}+6$ isotopomer.

\section{Western Blot Analysis of IL-10}

Plasma and adipose tissues samples collected on treatment d 7 were analyzed for IL-10 content using a semiquantitative Western blot assay. Adipose tissue $(\sim 20 \mathrm{mg})$ was homogenized at $4^{\circ} \mathrm{C}$ in RIPA lysis buffer (Santa Cruz Biotechnology, Santa Cruz, CA) containing a broad-spectrum protease inhibitor cocktail (Protease Inhibitor Cocktail I; Calbiochem, Gibbstown, NJ). The homogenate was centrifuged at $1,500 \times g$ for $1 \mathrm{~min}$ at $25^{\circ} \mathrm{C}$ and the protein content of the supernatant was measured with Coomassie blue. For the Western blot, samples $(1 \mu \mathrm{L}$ of plasma or $40 \mu \mathrm{g}$ of protein from adipose tissue) were diluted in Laemmli sample buffer, heated at $90^{\circ} \mathrm{C}$ for $5 \mathrm{~min}$, cooled, vortexed, separated by SDS-PAGE on a 4 to $12 \%$ Tris- $\mathrm{HCl}$ gel, and drytransferred onto nitrocellulose membranes (iBlot; Invitrogen, Carlsbad, CA). Membranes were blocked in Tris buffer ( $\mathrm{pH} 7.4$ ) with 5\% dry milk powder for $2 \mathrm{~h}$ 
at room temperature, then incubated for $1 \mathrm{~h}$ at room temperature with a rabbit anti-IL10 antibody (catalog \#sc-2313, Santa Cruz Biotechnology) diluted 1:500 for adipose samples or 1:1,000 for plasma samples. After washing, membranes were incubated for $1 \mathrm{~h}$ at room temperature with a secondary antibody (goat antirabbit IgG-HRP, catalog \#sc-2033, Santa Cruz Biotechnology) diluted 10,000-fold in Tris buffer ( $\mathrm{pH} 7.4$ ). Immunodetection was performed by chemiluminescence (West-Dura; Thermo Scientific, Waltham, MA) using a digital photodocumentation system (ChemiDocIt Imaging System; UVP Inc., Upland, CA). ImageJ software (National Institutes of Health, Bethesda, MD) was used for densitomery analysis. Western blot analysis was completed twice and densitometry values were averaged for statistical analysis. In both plasma and adipose samples, only the dimeric form of IL-10 (37 $\mathrm{kDa}$ ) was detected.

\section{Liver Tissue Analyses}

Triglyceride content of liver tissue was measured as previously described (Mullins et al., 2012). Quantitative real-time PCR was used to measure transcript abundance of key cytokines as well as genes involved in hepatic gluconeogenesis. Total RNA was isolated from liver tissue using a commercial kit (RNeasy Lipid Tissue Mini Kit, Qiagen, Valencia, CA). Ultraviolet spectroscopy was used to quantify RNA (Nanodrop-1000, Nanodrop Technologies Inc., Wilmington, DE). Quality of RNA was assessed (Bioanalyzer, Agilent Technologies, Santa Clara, CA) and RNA integrity number values were $6.2 \pm 0.8$ (mean $\pm \mathrm{SD}$ ). A high-capacity cDNA reverse transcription kit (Applied Biosystems, Foster City, CA) was used for synthesis of cDNA from $2 \mu \mathrm{g}$ of total RNA. Quantitative real-time PCR was performed in triplicate with $5 \%$ of the cDNA product in the presence of $200 \mathrm{nmol} / \mathrm{L}$ of gene-specific forward and reverse primers using SYBR green fluorescent detection (ABI 7500 Fast, Applied Biosystems). Messenger RNA abundance was quantified using the delta cycle threshold (Ct) method, with the geometric mean of ribosomal protein submit 9 , ribosomal protein submit 15 , and $\beta$-actin used to normalize values. Reference gene $\mathrm{Ct}$ values were not affected by treatment (all $P$ $>0.25)$. Primer sequences and reaction efficiencies are detailed in Supplemental Table S1 (http://www.dx.doi. org/10.3168/jds.2013-7777).

\section{Statistical Analysis}

Repeated measures results were modeled (SAS 9.2, SAS Institute, Cary, NC) with the fixed effects of treatment, day, and treatment $\times$ day interaction and the random effect of block. Repeated measures within cow were modeled with an autoregressive (AR[1]) covariance structure, and denominator degrees of freedom were estimated by the Kenward-Rogers method. Analysis of milk variables included pretreatment values as covariates to account for differences between animals at the beginning of the study. Single time point results were modeled (JMP 8.0, SAS Institute) with the fixed effect of treatment and the random effect of block. Several variables [liver tumor necrosis factor $\alpha$ (TNFA), IL10, IL-1 receptor 1 (IL1R1), plasma haptoglobin, IL-4, IL6 , TNFo, and IFN $\gamma$ )] were natural log-transformed for statistical analysis to achieve normal residual distributions, and reported means were back-transformed.

\section{RESULTS}

Continuous administration of TNF $\alpha$ in the tail-head adipose depot caused an apparent increase in local swelling, but did not increase body temperatures (data not shown). Circulating concentrations of TNFo, IFN $\gamma$, IL-6, and IL-4 were determined to assess the effect of treatment on inflammatory mediators. None of these cytokines were altered by treatment (Table 2); however, concentrations of the acute phase protein haptoglobin were elevated by TNFo treatment (Figure 1).

Treatment failed to alter feed intake, milk production, or composition of milk (Table 3). Furthermore, the proportion of short- and medium-chain FA $(<\mathrm{C} 16$, derived from de novo synthesis) in milk did not differ between treatments $(21.2$ vs. $20.6 \pm 1.2 \mathrm{~g} / 100 \mathrm{~g}$ of FA for control vs. TNFo, respectively), providing no evidence of a shift in source of milk FA.

Liver TG concentration did not differ between treatments (Figure 2). To investigate hepatic glucose metabolism, we quantified plasma glucose turnover rate. In ruminants, the glucose turnover rate is essentially equal to the gluconeogenic rate because the net portal appearance of glucose is negligible (Reynolds et al., 1988). The glucose turnover rate did not differ between treatments (Figure 2). Likewise, mRNA abundance of the gluconeogenic enzyme phosphoenolpyruvate carboxykinase $(P C K 1)$ was unaltered $(P=0.51)$, although TNFo treatment tended to decrease transcript abundance of $P C$, another key gluconeogenic enzyme $(P=$ 0.08 , Figure 3A). Neither plasma glucose nor insulin concentrations were altered by treatment (Table 2). Plasma NEFA concentration was measured as a proxy for lipolytic rate and BHBA concentration as an index of ketogenesis; neither variable was altered by treatment (Table 2).

Additionally, liver mRNA abundance of selected pro- and anti-inflammatory cytokines were measured to assess tissue-specific responses. In the liver (Figure 
Table 2. Effects of continuous infusion of tumor necrosis factor- $\alpha(\mathrm{TNF} \alpha)$ on plasma metabolites and endocrine factors ${ }^{1}$

\begin{tabular}{|c|c|c|c|c|}
\hline \multirow[b]{2}{*}{ Item } & \multicolumn{2}{|c|}{ Treatment } & \multirow[b]{2}{*}{ SEM } & \multirow[b]{2}{*}{$P$-value } \\
\hline & Control & TNF $\alpha$ & & \\
\hline $\mathrm{TNF} \alpha, \mathrm{p} M$ & 0.37 & 0.35 & 0.20 & 0.95 \\
\hline IFN $\gamma, \mathrm{p} M$ & 0.62 & 0.81 & 0.22 & 0.54 \\
\hline IL-4, pM & 0.59 & 0.47 & 0.47 & 0.84 \\
\hline IL-6, p $M$ & 2.9 & 6.5 & 2.6 & 0.29 \\
\hline Glucose, $\mathrm{m} M$ & 3.31 & 3.34 & 0.10 & 0.64 \\
\hline NEFA, $\mu M$ & 127 & 134 & 19 & 0.81 \\
\hline BHBA, $\mu M$ & 496 & 476 & 37 & 0.84 \\
\hline Insulin, $\mathrm{p} M$ & 368 & 363 & 65 & 0.97 \\
\hline
\end{tabular}

${ }^{1}$ Glucose, NEFA, and BHBA concentrations represent means over the 7-d treatment period; no treatment $\times$ time interactions were significant. Insulin and cytokine concentrations were determined on $\mathrm{d} 7$ of treatment. Values are means and pooled SEM, $\mathrm{n}=9$ or 10 .

3A), TNFo treatment tended to decrease TNFA mRNA abundance by $43 \%(P=0.07)$ and IL1R1 mRNA by $70 \%(P=0.06)$, whereas $I L 10 \mathrm{mRNA}$ abundance was not altered by treatment $(P=0.18)$. Western blot analysis of IL-10 protein in adipose tissue showed a striking increase in this anti-inflammatory cytokine (Figure 3B). Because adipose tissue IL-10 was elevated by $\mathrm{TNF} \alpha$ infusion, we also performed a semiquantitative analysis of plasma IL-10 by Western blot. No differences in plasma IL-10 were detected $(P=0.54$, data not shown).

\section{DISCUSSION}

Previous research with once-daily subcutaneous injections of $\mathrm{TNF} \alpha$ to late-lactation dairy cows found that TNFo could increase liver TG concentration and tended to decrease hepatic mRNA abundance of ratelimiting enzymes for gluconeogenesis and FA oxidation (Bradford et al., 2009). Several other studies have likewise demonstrated substantial behavioral, endocrine, and metabolic responses to similar daily bolus doses of $\mathrm{TNF} \alpha$, even though changes in circulating $\mathrm{TNF} \alpha$

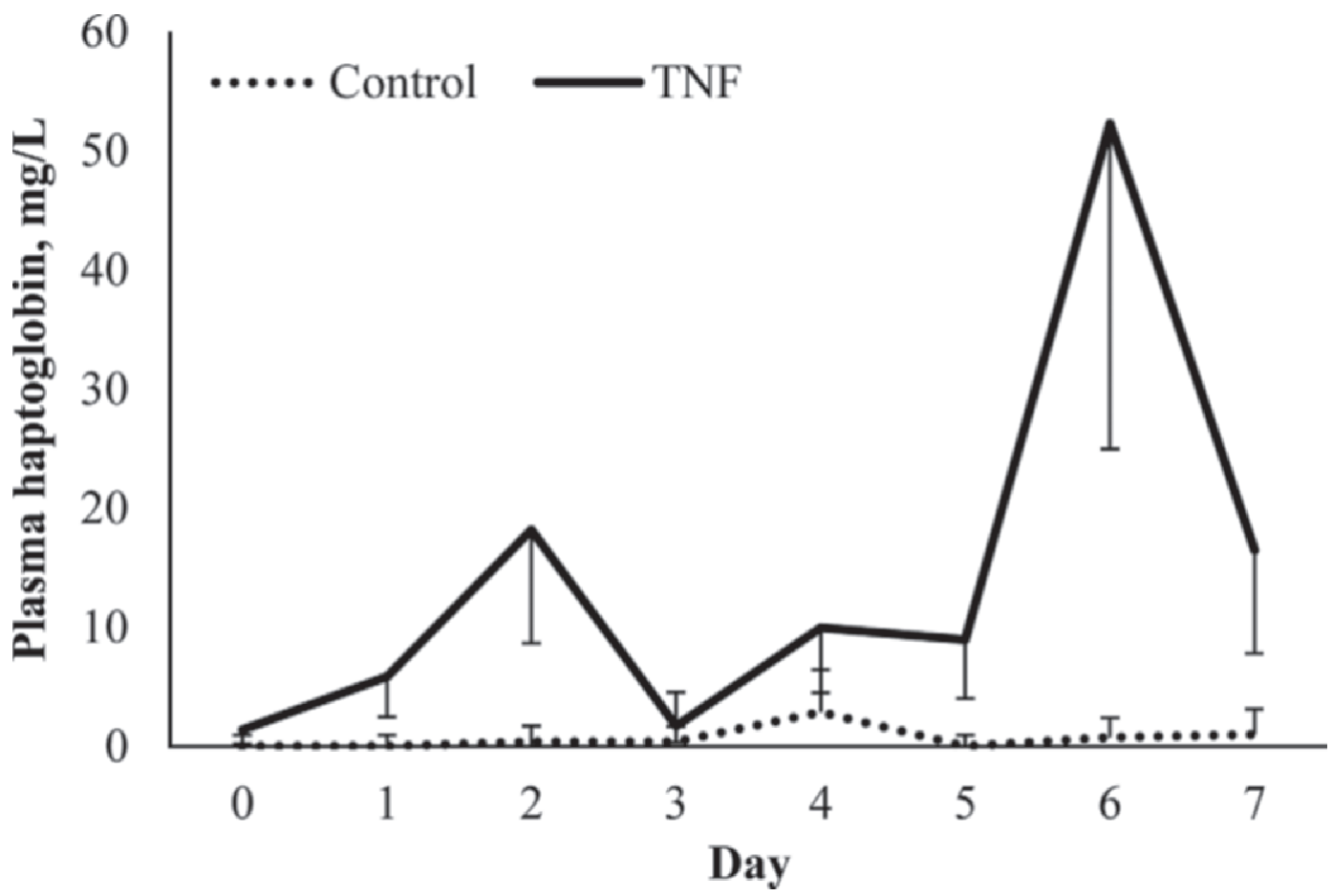

Figure 1. Plasma haptoglobin concentrations in lactating dairy cows continuously infused with saline (control) or $14 \mu \mathrm{g} / \mathrm{kg}$ of $\mathrm{BW}$ recombinant bovine tumor necrosis factor- $\alpha(\mathrm{TNF} \alpha)$ over $7 \mathrm{~d}$. Values are back-transformed means \pm SEM, $\mathrm{n}=9$ or 10 . Treatment $(P<0.001)$ and day $(P=0.03)$ effects were significant, but no treatment $\times$ day interaction was detected $(P=0.34)$. 
Table 3. Effects of continuous infusion of tumor necrosis factor- $\alpha(\mathrm{TNF} \alpha)$ on intake, milk production, and milk composition ${ }^{1}$

\begin{tabular}{|c|c|c|c|c|}
\hline \multirow[b]{2}{*}{ Item } & \multicolumn{2}{|c|}{ Infusion treatment } & \multirow[b]{2}{*}{ SEM } & \multirow[b]{2}{*}{$P$-value } \\
\hline & Control & $\mathrm{TNF} \alpha$ & & \\
\hline DMI, kg/d & 20.9 & 20.5 & 0.98 & 0.63 \\
\hline Milk yield, $\mathrm{kg} / \mathrm{d}$ & 30.0 & 30.5 & 1.23 & 0.72 \\
\hline Milk fat, $\mathrm{kg} / \mathrm{d}$ & 1.14 & 1.07 & 0.066 & 0.43 \\
\hline Milk fat, $\%$ & 3.80 & 3.52 & 0.16 & 0.28 \\
\hline Milk protein, $\mathrm{kg} / \mathrm{d}$ & 0.98 & 0.97 & 0.041 & 0.83 \\
\hline Milk protein, \% & 3.25 & 3.23 & 0.023 & 0.57 \\
\hline Milk lactose, $\mathrm{kg} / \mathrm{d}$ & 1.47 & 1.50 & 0.059 & 0.68 \\
\hline Milk lactose, $\%$ & 4.90 & 4.91 & 0.023 & 0.79 \\
\hline
\end{tabular}

${ }^{1}$ Values are means and pooled SEM, $\mathrm{n}=9$ or 10 .

concentrations are marginal at these administration rates (Kushibiki et al., 2003; Yuan et al., 2013). We expected that continuous TNFo administration at the same dose $(2 \mu \mathrm{g} / \mathrm{kg}$ of BW per day) would better mimic endogenous TNFo release and would subsequently alter insulin sensitivity, increase plasma NEFA concentration through induction of lipolysis, and promote hepatic TG accumulation. In contrast, administration of $\mathrm{TNF} \alpha$ through osmotic pumps did not significantly alter liver TG concentration following the 7 -d treatment period (Figure 2).

Prior studies evaluating the effects of continuous $\mathrm{TNF} \alpha$ administration have generally mimicked acute, rather than chronic, inflammation. Continuous administration of $100 \mu \mathrm{g}$ of $\mathrm{TNF} \alpha$ over $7 \mathrm{~d}$ in mice, for example, increased serum $\mathrm{TNF} \alpha$ concentrations by approximately 500-fold (Matsuno et al., 2002). Concentrations of nearly $10 \mathrm{ng} / \mathrm{mL}$ achieved in that study are relevant for studying acute endotoxemia (Kenison et al., 1991), but TNF $\alpha$ concentrations of this level are clearly supraphysiological in dairy cows during the transition to lactation, when mean concentrations range from 1 to $10 \mathrm{pg} / \mathrm{mL}$ and rarely exceed $100 \mathrm{pg} /$ $\mathrm{mL}$ in individuals (Schoenberg et al., 2011; Farney et al., 2013; Yuan et al., 2013). Other continuous infusion studies have demonstrated immune cell infiltration of muscle (Peterson et al., 2006) and suppression of plasma TG (Sweep et al., 1992a) and thyroxine (Sweep et al., 1992b) concentrations in rodents receiving 20 to $100 \mu \mathrm{g} / \mathrm{kg}$ daily for $7 \mathrm{~d}$. Our dose of $2 \mu \mathrm{g} / \mathrm{kg}$ per day

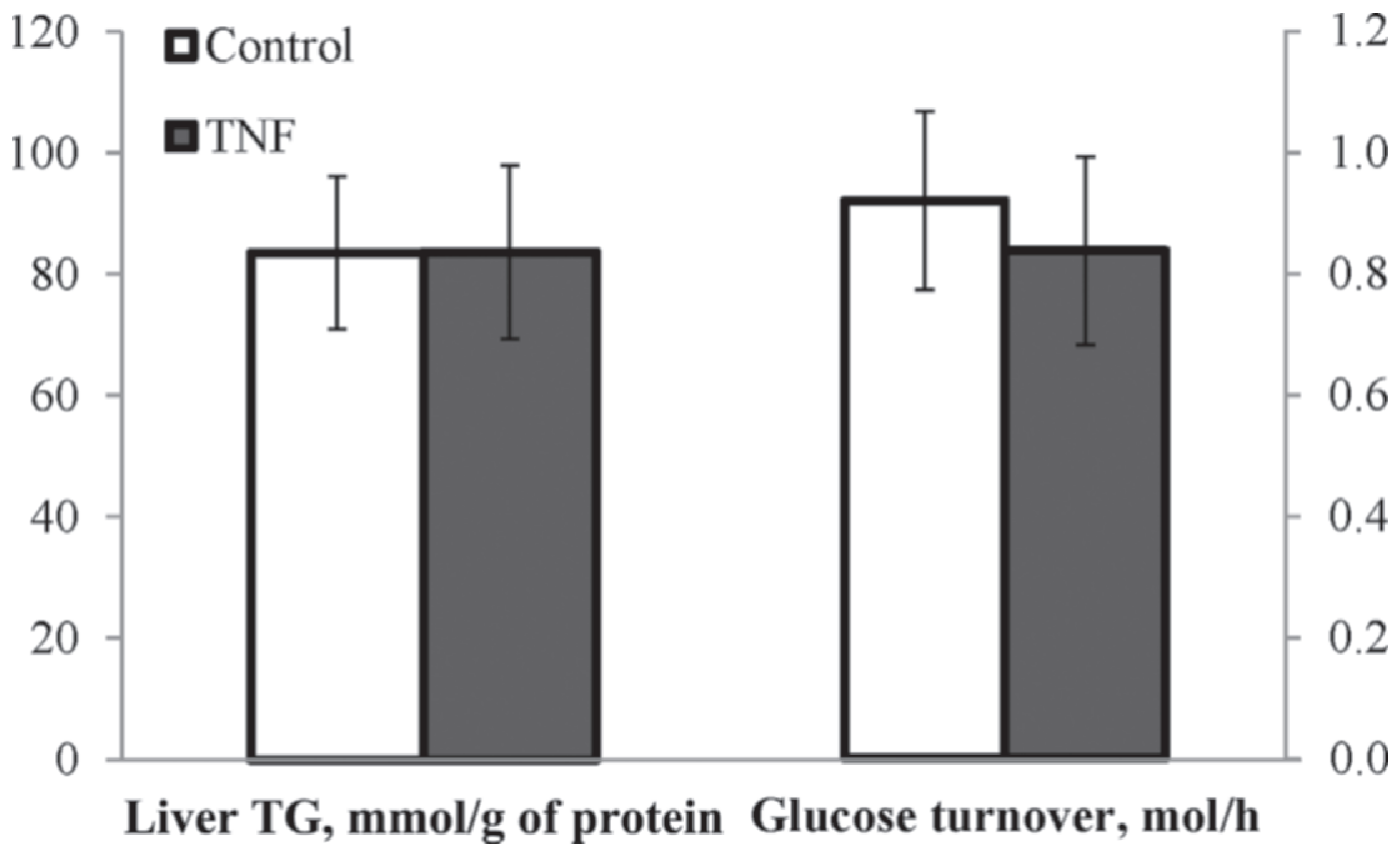

Figure 2. Liver triglyceride (TG) concentration and plasma glucose turnover rate in lactating dairy cows continuously infused with saline (control) or $14 \mu \mathrm{g} / \mathrm{kg}$ of BW recombinant bovine tumor necrosis factor- $\alpha(\mathrm{TNF} \alpha)$ over $7 \mathrm{~d}$. Values are means $\pm \mathrm{SEM}, \mathrm{n}=9$ or 10 . Treatment did not alter liver TG concentration (left axis, $P=0.99$ ) or glucose turnover rate (right axis, $P=0.24$ ). 


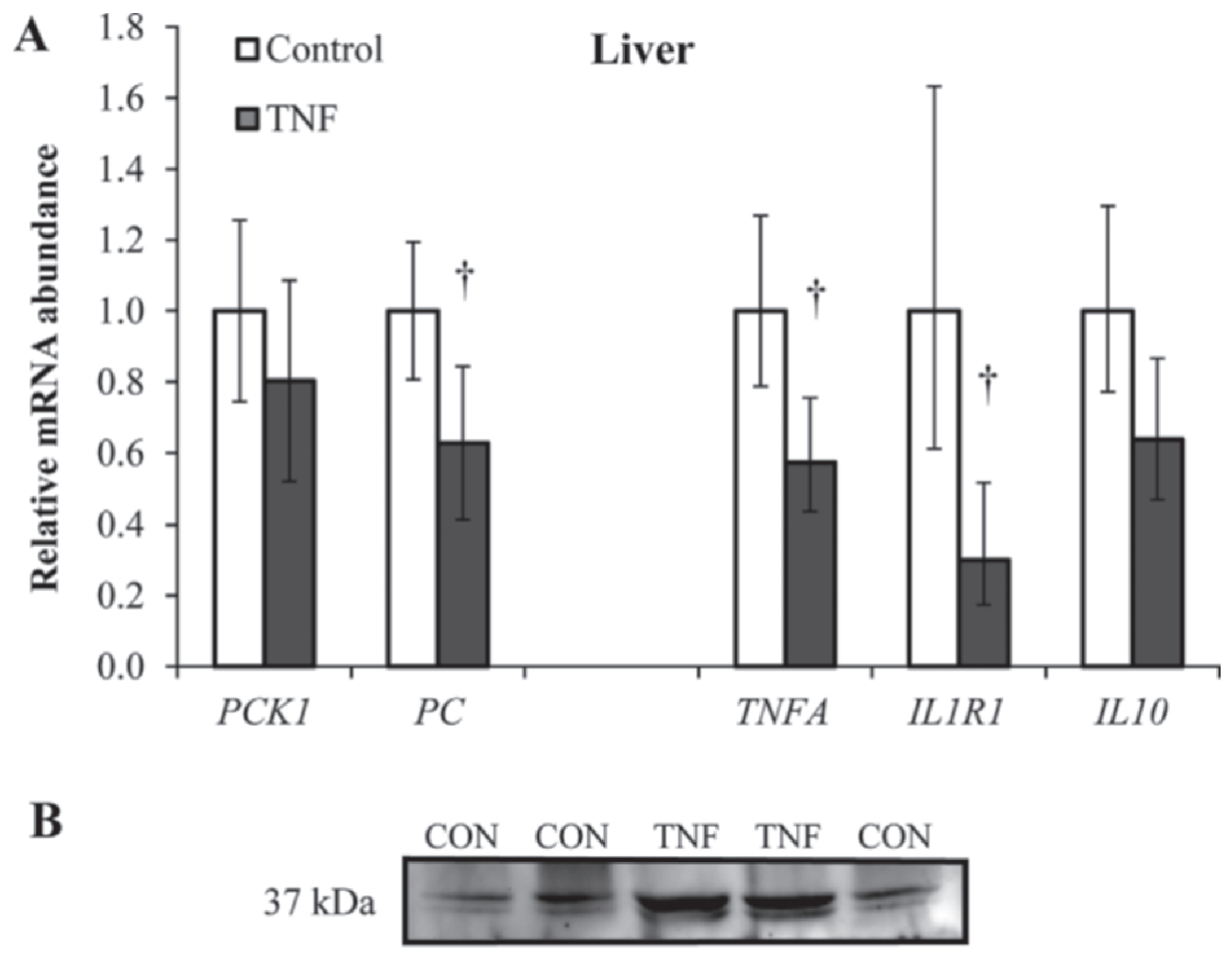

Adipose IL-10

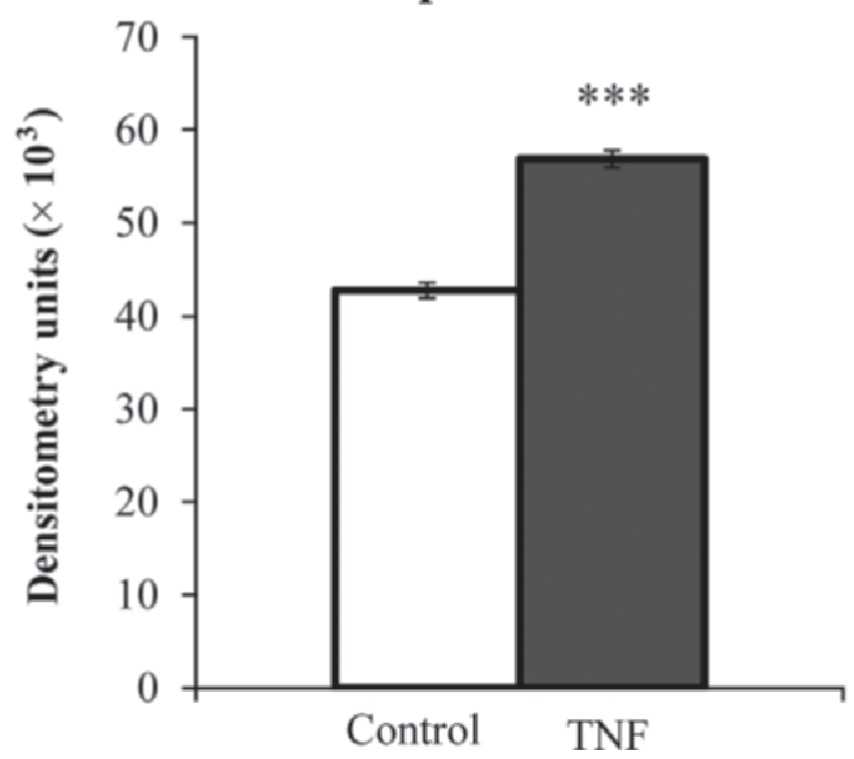

Figure 3. Liver transcript abundance and adipose tissue IL-10 concentrations in lactating dairy cows continuously infused with saline (control) or $14 \mu \mathrm{g} / \mathrm{kg}$ of BW recombinant bovine tumor necrosis factor- $\alpha$ (TNF $\alpha$ ) over $7 \mathrm{~d}$. (A) Transcripts involved in nutrient metabolism and inflammatory signaling in liver were quantified by quantitative real-time PCR. Values for TNFA, IL1R1, and IL10 were back-transformed after analysis of log-transformed data. (B) Adipose tissue IL-10 protein concentration was assessed by Western blot; tissue collected was contralateral to the site of TNFo administration to avoid local effects. A representative blot image and the results of densitometry analysis are shown. All values are means \pm SEM, $\mathrm{n}=9$ or $10 ; \dagger P<0.10$; ${ }^{* * *} P<0.001$. 
was therefore dramatically lower than those reported to have these acute responses, and the dose was chosen based on its efficacy in previous work (Kushibiki et al., 2003; Bradford et al., 2009; Yuan et al., 2013). The fact that plasma haptoglobin was elevated by our treatment regimen (Figure 1) validates the systemic relevance of this model system, even though we did not detect a change in plasma TNF $\alpha$ concentration (Table 2).

Despite the small number of significant treatment effects observed in the current study, 2 key insights can be gleaned from this work. First, these observations suggest that identical low doses of TNFo cause very different responses when administered in daily subcutaneous boluses versus continuous infusion in a subcutaneous adipose depot. In essentially all other respects, the design of the current study was identical to one that showed increased liver TG content and substantial alterations in metabolic transcripts in the liver following $7 \mathrm{~d}$ of TNFo administration (Bradford et al., 2009). Although we are unaware of reports directly comparing repeated bolus doses of $\mathrm{TNF} \alpha$ to continuous administration, responses to bolus versus sustained administration of the same dose of LPS have been evaluated (Taudorf et al., 2007). This study in humans showed that bolus administration of LPS induced a more rapid $\mathrm{TNF} \alpha$ response and led to significantly higher plasma IL-6 concentrations and neutrophil counts over the course of the 8-h observation period (Taudorf et al., 2007). That more dramatic increases in inflammatory agents induce greater responses than sustained, lowlevel administration is not surprising. Inflammatory cascades can initiate an amplification process known as the cytokine storm (Tisoncik et al., 2012). Once the threshold for this response is reached, endogenous production of $\mathrm{TNF} \alpha$, other proinflammatory cytokines, and chemokines is capable of sustaining the inflammatory profile well beyond the point when the administered agent is cleared. With continuous administration protocols, this threshold may not be reached.

The other intriguing finding herein was the antiinflammatory response observed in liver and adipose tissue. In our prior study with daily bolus doses, peripheral administration of $\mathrm{TNF} \alpha$ increased $T N F A$ mRNA in the liver, suggesting the activation of inflammatory transcriptional programs (Bradford et al., 2009). Therefore, it was surprising to find evidence of increased IL-10 in adipose tissue, as well as possible decreases in TNFA and IL1R1 mRNA in liver. Interleukin 1 receptor 1 mediates most of the effects of the proinflammatory cytokine IL-1 $\beta$ (Sims et al., 1993), so a decrease in its expression is consistent with a decrease in inflammatory signal transduction, as is the decrease in TNFA. Interleukin-10 is one of the bestcharacterized anti-inflammatory cytokines (Fiorentino et al., 1991; Banchereau et al., 2012), and an increase in production of this protein in adipose tissue distant from the site of pump implantation clearly demonstrates an anti-inflammatory shift in this tissue.

Although the proinflammatory effects of $\mathrm{TNF} \alpha$ are typically the most overt, evidence of anti-inflammatory components of the cellular responses to TNFa has also been reported, involving at least 3 different mechanisms. Interleukin-10 production can be induced by inflammatory agents, such as TNFa (Giambartolomei et al., 2002). This response is usually considered a component of the resolution phase of inflammation, the well-characterized, preprogrammed wave of antiinflammatory compound release that follows the initial cytokine storm (Serhan, 2011). Another mechanism that may contribute to desensitization (tolerance) during continued exposure to $\mathrm{TNF} \alpha$ is the induction of suppressor of cytokine signaling 3. This protein interferes with signaling downstream of cytokine receptors, and TNFo increases its abundance by inhibiting degradation of both SOCS3 mRNA (Ehlting et al., 2007) and protein (Dagvadorj et al., 2010).

Transmembrane receptors for $\mathrm{TNF} \alpha$ mediate its inflammatory effects on cells, but these receptors can also be cleaved to release soluble forms that neutralize TNFo activity by preventing it from binding to intact receptors (Van Zee et al., 1992). Interestingly, TNF $\alpha$ itself promotes this cleavage process (Dri et al., 2000), and increased concentrations of soluble TNFa receptors have been directly implicated in the tolerance induced by low-dose pretreatment with either LPS (van Mierlo et al., 2008) or TNFo (Sass et al., 2002). Therefore, continuous low-dose $\mathrm{TNF} \alpha$ treatment may induce receptor cleavage and increase soluble $\mathrm{TNF} \alpha$ receptor concentrations, decreasing subsequent responses to the cytokine.

We propose that a combination of resolving phase signals, disruption of intracellular cytokine signaling, and $\mathrm{TNF} \alpha$ receptor shedding may have led to a state in which inflammation was suppressed in $\mathrm{TNF}$-treated cows to a greater extent than in the control animals. The idea that low-dose pretreatment with inflammatory agents can promote tolerance to larger subsequent challenges is well-documented, as discussed herein. More broadly, this phenomenon brings to mind the concept of hormesis, which proposes that compounds can generate very different responses at different doses, to the extent that a harmful agent at a high dose may be beneficial or protective at a low dose (Kolb and Eizirik, 2012). In fact, a fairly long list of immune system signals have been documented as inducing hormetic responses in a variety of model systems (Calabrese, 2005). The current work suggests that such responses may also depend on the pulsatility of administration. 
Our findings leave open the question about the relevance of adipose tissue-derived cytokines in dairy cattle. Because of the well-established links between adipose-associated inflammation and metabolic syndrome in humans and rodents (Olefsky and Glass, 2010), it has been proposed that adipose-derived inflammatory signals may provide the mechanistic link between high adipose tissue stores at parturition and increased risk of metabolic disorders in dairy cows. Recent evidence, however, has not supported this hypothesis. Plasma $\mathrm{TNF} \alpha$ concentrations are not greatly elevated during the periparturient period (Schoenberg et al., 2011), and adipose tissue from cows during this period clearly did not manifest the degree of immune cell infiltration observed in obese rodent models (Akter et al., 2012). Nevertheless, potentially important changes in adipose tissue endocrine profiles could affect systemic inflammatory status; for example, animals with greater adipose stores have decreased adiponectin concentrations (Frayn et al., 2003; Häussler et al., 2013). The attenuation of this anti-inflammatory signal may be an important, often overlooked effect of increased adiposity. The mechanistic effect of adipose tissue on metabolic disorders in dairy cows remains unclear, but endocrine factors other than TNFo are perhaps better candidates for continued investigation.

\section{CONCLUSIONS}

In contrast to our initial hypothesis, continuous administration of TNFo into a subcutaneous adipose tissue depot did not significantly alter systemic nutrient metabolism. Furthermore, TNFo treatment had limited effects on the inflammatory mediators measured, and several changes in adipose tissue and liver suggested a shift to a less inflammatory state. These findings are consistent with the concept that continuous lowdose $\mathrm{TNF} \alpha$ administration activates compensatory mechanisms to induce tolerance to TNF $\alpha$ and enhance anti-inflammatory factors. Compared against previous results, these findings also suggest that repeated bolus administration of TNFo induces much more dramatic effects on nutrient metabolism than continuous infusion of the same dose.

\section{ACKNOWLEDGMENTS}

The authors thank Jamie Hermann, Chad Mullins, Jaymelynn Farney, and Michelle Sullivan (Kansas State University, Manhattan, KS), as well as the staff of the Kansas State University Dairy Teaching and Research Center for assistance with this trial. This project was supported by National Research Initiative Competitive Grant no. 2009-35206-05271 from the USDA National
Institute of Food and Agriculture (Washington, DC). This is contribution number 14-075-J from the Kansas Agricultural Experiment Station (Manhattan). Mention of trade names or commercial products in this article is solely for the purpose of providing specific information and does not imply recommendation or endorsement by the USDA; USDA is an equal opportunity provider and employer.

\section{REFERENCES}

Akter, S. H., S. Haussler, D. Germeroth, D. von Soosten, S. Danicke, K. H. Sudekum, and H. Sauerwein. 2012. Immunohistochemical characterization of phagocytic immune cell infiltration into different adipose tissue depots of dairy cows during early lactation. J. Dairy Sci. 95:3032-3044.

Ametaj, B. N., B. J. Bradford, G. Bobe, R. A. Nafikov, Y. Lu, J. W Young, and D. C. Beitz. 2005. Strong relationships between mediators of the acute phase response and fatty liver in dairy cows. Can. J. Anim. Sci. 85:165-175.

Banchereau, J., V. Pascual, and A. O'Garra. 2012. From IL-2 to IL37: The expanding spectrum of anti-inflammatory cytokines. Nat. Immunol. 13:925-931.

Bionaz, M., E. Trevisi, L. Calamari, F. Librandi, A. Ferrari, and G. Bertoni. 2007. Plasma paraoxonase, health, inflammatory conditions, and liver function in transition dairy cows. J. Dairy Sci. 90:1740-1750.

Bobe, G., J. W. Young, and D. C. Beitz. 2004. Invited review: Pathology, etiology, prevention, and treatment of fatty liver in dairy cows. J. Dairy Sci. 87:3105-3124.

Bradford, B. J., L. K. Mamedova, J. E. Minton, J. S. Drouillard, and B. J. Johnson. 2009. Daily injection of tumor necrosis factor- $\alpha$ increases hepatic triglycerides and alters transcript abundance of metabolic genes in lactating dairy cattle. J. Nutr. 139:1451-1456.

Calabrese, E. J. 2005. Hormetic dose-response relationships in immunology: Occurrence, quantitative features of the dose response, mechanistic foundations, and clinical implications. Crit. Rev. Toxicol. 35:89-295.

Carroll, J. A., J. D. Arthington, and C. C. Chase Jr. 2009. Early weaning alters the acute-phase reaction to an endotoxin challenge in beef calves. J. Anim. Sci. 87:4167-4172.

Cerami, A., Y. Ikeda, N. Le Trang, P. J. Hotez, and B. Beutler. 1985. Weight loss associated with an endotoxin-induced mediator from peritoneal macrophages: The role of cachectin (tumor necrosis factor). Immunol. Lett. 11:173-177.

Cooke, R. F., and J. D. Arthington. 2013. Concentrations of haptoglobin in bovine plasma determined by ELISA or a colorimetric method based on peroxidase activity. J. Anim. Physiol. Anim. Nutr. (Berl.) 97:531-536.

Dagvadorj, J., Y. Naiki, G. Tumurkhuu, A. S. Noman, E. K. I. Iftakhar, T. Komatsu, N. Koide, T. Yoshida, and Y. Takashi. 2010. Tumor necrosis factor-a augments lipopolysaccharide-induced suppressor of cytokine signalling 3 (SOCS-3) protein expression by preventing the degradation. Immunology 129:97-104.

Daniel, J. A., T. H. Elsasser, C. D. Morrison, D. H. Keisler, B. K. Whitlock, B. Steele, D. Pugh, and J. L. Sartin. 2003. Leptin, tumor necrosis factor- $\alpha$ (TNF), and CD14 in ovine adipose tissue and changes in circulating TNF in lean and fat sheep. J. Anim. Sci. 81:2590-2599.

Dri, P., C. Gasparini, R. Menegazzi, R. Cramer, L. Albéri, G. Presani, S. Garbisa, and P. Patriarca. 2000. TNF-induced shedding of TNF receptors in human polymorphonuclear leukocytes: role of the 55$\mathrm{kDa}$ TNF receptor and involvement of a membrane-bound and non-matrix metalloproteinase. J. Immunol. 165:2165-2172.

Ehlting, C., W. S. Lai, F. Schaper, E. D. Brenndorfer, R. J. Matthes, P. C. Heinrich, S. Ludwig, P. J. Blackshear, M. Gaestel, D. Haussinger, and J. G. Bode. 2007. Regulation of suppressor of cytokine signaling 3 (SOCS3) mRNA stability by TNF-alpha 
involves activation of the MKK6/p38MAPK/MK2 cascade. J. Immunol. 178:2813-2826.

Endo, M., T. Masaki, M. Seike, and H. Yoshimatsu. 2007. TNF-o induces hepatic steatosis in mice by enhancing gene expression of sterol regulatory element binding protein-1c (SREBP-1c). Exp. Biol. Med. (Maywood) 232:614-621.

Farney, J. K., L. K. Mamedova, J. F. Coetzee, B. KuKanich, L. M. Sordillo, S. K. Stoakes, J. E. Minton, L. C. Hollis, and B. J. Bradford. 2013. Anti-inflammatory salicylate treatment alters the metabolic adaptations to lactation in dairy cattle. Am. J. Physiol. Regul. Integr. Comp. Physiol. 305:R110-R117.

Farney, J. K., L. K. Mamedova, B. H. Godsey, and B. J. Bradford. 2011. Technical note: Validation of an ELISA for measurement of tumor necrosis factor alpha in bovine plasma. J. Dairy Sci. 94:3504-3509.

Fiers, W. 1991. Tumor necrosis factor: Characterization at the molecular, cellular and in vivo level. FEBS Lett. 285:199-212.

Fiorentino, D. F., A. Zlotnik, T. R. Mosmann, M. Howard, and A. O'Garra. 1991. IL-10 inhibits cytokine production by activated macrophages. J. Immunol. 147:3815-3822.

Frayn, K. N., F. Karpe, B. A. Fielding, I. A. Macdonald, and S. W. Coppack. 2003. Integrative physiology of human adipose tissue. Int. J. Obes. Relat. Metab. Disord. 27:875-888.

Giambartolomei, G. H., V. A. Dennis, B. L. Lasater, P. K. Murthy and M. T. Philipp. 2002. Autocrine and exocrine regulation of interleukin-10 production in THP-1 cells stimulated with Borrelia burgdorferi lipoproteins. Infect. Immun. 70:1881-1888.

Häussler, S., S. P. Singh, L. Laubenthal, L. Locher, J. Winkler, U. Meyer, S. Dänicke, and H. Sauerwein. 2013. Impact of increased oxidative stress through excessive accumulation of adipose tissue on circulating adiponectin concentrations in dairy cows. J. Dairy Sci. 96(E-Suppl. 1):114

Hotamisligil, G. S., N. S. Shargill, and B. M. Spiegelman. 1993. Adipose expression of tumor necrosis factor-alpha: Direct role in obesity-linked insulin resistance. Science 259:87-91.

Kenison, D. C., T. H. Elsasser, and R. Fayer. 1991. Tumor necrosis factor as a potential mediator of acute metabolic and hormonal responses to endotoxemia in calves. Am. J. Vet. Res. 52:1320-1326.

Kolb, H., and D. Eizirik. 2012. Resistance to type 2 diabetes mellitus: A matter of hormesis? Nat. Rev. Endocrinol. 8:183-192.

Kushibiki, S., K. Hodate, H. Shingu, T. Hayashi, E. Touno, M. Shinoda, and Y. Yokomizo. 2002. Alterations in lipid metabolism induced by recombinant bovine tumor necrosis factor-alpha administration to dairy heifers. J. Anim. Sci. 80:2151-2157.

Kushibiki, S., K. Hodate, H. Shingu, Y. Obara, E. Touno, M. Shinoda, and Y. Yokomizo. 2003. Metabolic and lactational responses during recombinant bovine tumor necrosis factor- $\alpha$ treatment in lactating cows. J. Dairy Sci. 86:819-827.

Kushibiki, S., K. Hodate, H. Shingu, Y. Ueda, M. Shinoda, Y. Mori, T. Itoh, and Y. Yokomizo. 2001. Insulin resistance induced in dairy steers by tumor necrosis factor alpha is partially reversed by 2,4-thiazolidinedione. Domest. Anim. Endocrinol. 21:25-37.

Matsuno, H., K. Yudoh, R. Katayama, F. Nakazawa, M. Uzuki, T. Sawai, T. Yonezawa, Y. Saeki, G. S. Panayi, C. Pitzalis, and T. Kimura. 2002. The role of TNF- $\alpha$ in the pathogenesis of inflammation and joint destruction in rheumatoid arthritis (RA): A study using a human RA/SCID mouse chimera. Rheumatology (Oxford) 41:329-337.

Mullins, C. R., L. K. Mamedova, M. J. Brouk, C. E. Moore, H. B. Green, K. L. Perfield, J. F. Smith, J. P. Harner, and B. J. Bradford. 2012. Effects of monensin on metabolic parameters, feeding behavior, and productivity of transition dairy cows. J. Dairy Sci. 95:1323-1336.

NRC. 2001. Nutrient Requirements of Dairy Cattle. 7th rev. ed. Natl. Acad. Sci., Washington, DC.

Olefsky, J. M., and C. K. Glass. 2010. Macrophages, inflammation, and insulin resistance. Annu. Rev. Physiol. 72:219-246.

Peterson, J. M., K. D. Feeback, J. H. Baas, and F. X. Pizza. 2006. Tumor necrosis factor- $\alpha$ promotes the accumulation of neutrophils and macrophages in skeletal muscle. J. Appl. Physiol. 101:13941399.

Popa, C., M. G. Netea, P. L. C. M. van Riel, J. W. M. van der Meer, and A. F. H. Stalenhoef. 2007. The role of TNF- $\alpha$ in chronic inflammatory conditions, intermediary metabolism, and cardiovascular risk. J. Lipid Res. 48:751-762.

Reynolds, C. K., G. B. Huntington, H. F. Tyrrell, and P. J. Reynolds. 1988. Net portal-drained visceral and hepatic metabolism of glucose, L-lactate, and nitrogenous compounds in lactating Holstein cows. J. Dairy Sci. 71:1803-1812.

Sass, G., K. Koerber, and G. Tiegs. 2002. TNF tolerance and cytotoxicity in the liver: The role of interleukin-13, inducible nitric oxide-synthase and heme oxygenase-1 in D-galactosamine-sensitized mice. Inflamm. Res. 51:229-235.

Schoenberg, K. M., K. L. Perfield, J. K. Farney, B. J. Bradford, Y. R. Boisclair, and T. R. Overton. 2011. Effects of prepartum 2,4-thiazolidinedione on insulin sensitivity, plasma concentrations of tumor necrosis factor- $\alpha$ and leptin, and adipose tissue gene expression. J. Dairy Sci. 94:5523-5532.

Schulze, E., H. Fuhrmann, E. S. Neitzel, W. W. Giese, and H. P. Sallmann. 1991. Glucose entry rate in dairy cattle as determined by stable isotope ${ }^{13} \mathrm{C}$-labelled glucose at different stages of reproduction. Comp. Biochem. Physiol. B 100:167-171.

Serhan, C. N. 2011. The resolution of inflammation: The devil in the flask and in the details. FASEB J. 25:1441-1448.

Shoelson, S. E., L. Herrero, and A. Naaz. 2007. Obesity, inflammation, and insulin resistance. Gastroenterology 132:2169-2180.

Sims, J. E., M. A. Gayle, J. L. Slack, M. R. Alderson, T. A. Bird, J. G. Giri, F. Colotta, F. Re, A. Mantovani, and K. Shanebeck. 1993. Interleukin 1 signaling occurs exclusively via the type I receptor. Proc. Natl. Acad. Sci. USA 90:6155-6159.

Sukhija, P. S., and D. L. Palmquist. 1988. Rapid method for determination of total fatty acid content and composition of feedstuffs and feces. J. Agric. Food Chem. 36:1202-1206.

Sweep, C. G., R. M. Hermus, M. J. van der Meer, P. N. Demacker, T. J. Benraad, and P. W. Kloppenborg. 1992a. Chronic intraperitoneal infusion of low doses of tumor necrosis factor alpha in rats induces a reduction in plasma triglyceride levels. Cytokine 4:561-567

Sweep, C. G., M. J. van der Meer, H. A. Ross, R. Vranckx, T. J Visser, and A. R. Hermus. 1992b. Chronic infusion of TNF-alpha reduces plasma T4 binding without affecting pituitary-thyroid activity in rats. Am. J. Physiol. 263:E1099-E1105.

Taudorf, S., K. S. Krabbe, R. M. G. Berg, B. K. Pedersen, and K. Møller. 2007. Human models of low-grade inflammation: Bolus versus continuous infusion of endotoxin. Clin. Vaccine Immunol. $14: 250-255$

Tisoncik, J. R., M. J. Korth, C. P. Simmons, J. Farrar, T. R. Martin, and M. G. Katze. 2012. Into the eye of the cytokine storm. Microbiol. Mol. Biol. Rev. 76:16-32.

Tserng, K. Y., and S. C. Kalhan. 1983. Estimation of glucose carbon recycling and glucose turnover with $[\mathrm{U}-13 \mathrm{C}]$ glucose. Am. J. Physiol. 245:E476-E482.

van Mierlo, G. J. D., H. U. Scherer, M. Hameetman, M. E. Morgan, R. Flierman, T. W. J. Huizinga, and R. E. M. Toes. 2008. Cutting edge: TNFR-shedding by $\mathrm{CD} 4^{+} \mathrm{CD} 25^{+}$regulatory $\mathrm{T}$ cells inhibits the induction of inflammatory mediators. J. Immunol. 180:2747-2751.

Van Zee, K. J., T. Kohno, E. Fischer, C. S. Rock, L. L. Moldawer, and S. F. Lowry. 1992. Tumor necrosis factor soluble receptors circulate during experimental and clinical inflammation and can protect against excessive tumor necrosis factor alpha in vitro and in vivo. Proc. Natl. Acad. Sci. USA 89:4845-4849.

Yuan, K., J. K. Farney, L. K. Mamedova, L. M. Sordillo, and B. J. Bradford. 2013. TNF $\alpha$ altered inflammatory responses, impaired health and productivity, but did not affect glucose or lipid metabolism in early-lactation dairy cows. PLoS ONE 8:e80316. 